\title{
UJICOBA PENANAMAN LADA - LADA (Micromelum minutum) UNTUK PEMBINAAN HABITAT KUPU - KUPU DITAMAN NASIONAL BANTIMURUNG BULUSARAUNG
}

\author{
Planting Trial of Butterfly Feed Plants for Habitat Improvement \\ in Bantimurung Bulusaraung National Park
}

Heri Suryanto'

\begin{abstract}
Butterfly is a typical fauna in Bantimurung Bulusaraung National Park. Their population are more and more decreased in nature due to decreasing of feed plant of butterfly caused by logging and encroachment. In order to get effective and efficient planting method, research was conducted. Butterfly improvement research in Bantimurung Bulusaraung National Park was carried out in the evaluation of plant growth. Planting trials were carried out in using the Randomysed Completely Block Design (RCBD) method with 4 levels of fertilization treatment, i.e control, $300 \mathrm{gr}$ fertilizer dosage for planting holes, $600 \mathrm{gr}$ for planting holes and $900 \mathrm{~g}$ for planting holes. The results showed that the best dose of manure in $600 \mathrm{gr}$ treatment gave the best value of number of leaves.Chlorosis made growth of the plants were not optimal due to the soil have fast drainage physical properties.
\end{abstract}

Keywords : Bantimurung Bulusaraung National Park, habitat improvement,butterfly feed plant,plot demonstration

\begin{abstract}
ABSTRAK
Kupu-kupu merupakan fauna khas di Taman Nasional (TN) Bantimurung Bulusaraung. Populasinya di alam kian lama kian menurun disebabkan turunnya populasi pakan akibat penebangan dan perambahan. Pembinaan habitat dilakukan untuk menjaga kelestarian spesies kupu-kupu tersebut. Guna mendapatkan metode penanaman yang tepat maka dilakukan penelitian. Ujicoba penanaman dengan metode Randomysed Completely Block Design (RCBD) dengan 4 taraf perlakuan pemupukan yaitu kontrol, takaran pupuk 300 gr per lubang tanam, 600 gr per lubang tanam dan 900 gr per lubang tanam. Hasil penelitian menunjukkan bahwa jumlah daun terbanyak diperoleh dengan perlakuan pada dosis 600 gr per lubang tanam. Terjadinya klorosis menyebabkan tanaman tidak tumbuh optimal pada media tanah di lokasi penelitian yang memiliki kondisi drainase cepat.
\end{abstract}

Kata Kunci : Taman Nasional Bantimurung Bulusaraung, pembinaan habitat kupu-kupu, tanaman pakan, plot demonstrasi

\begin{tabular}{lll} 
Author Institution & $:$ & $\begin{array}{l}\text { IPeneliti Balai Penelitian dan Pengembangan Lingkungan Hidup dan Kehutanan Makassar - Jalan Perntis } \\
\text { kemerdekaan km 16.5 Makassar 62-4I I-554049 }\end{array}$ \\
$\begin{array}{l}\text { Koresponding Author } \\
\text { Articel History }\end{array}$ & $\begin{array}{l}\text { 04II-554049; heribpkm@yahoo.com } \\
\text { Received 2IFebruary 2019; received in revised from 26 April 2019; accepted 26 April 2019; Available online since } \\
\end{array}$ \\
\hline
\end{tabular}




\section{PENDAHULUAN}

Jumlah populasi dan spesies kupu-kupu Bantimurung kian lama kian menurun, beberapa diantaranya bahkan berada diambang kepunahan. Kecenderungan penurunan populasi jenis kupu-kupu tersebut disebabkan oleh degradasi habitat kupu-kupu akibat tekanan penduduk, perambahan kawasan dan aktivitas wisata di Taman Wisata Alam (TWA) Bantimurung serta karena adanya kegiatan penangkapan kupu-kupu secara liar (Balai Konservasi Sumber Daya Alam Sulawesi Selatan, 2005). Guna menjaga keberadaan populasi jenis tumbuhan dan satwa kupu-kupu dalam keadaan seimbang dengan daya dukung habitatnya maka perlu dilaksanakan pembinaan habitat kupu-kupu di Taman Nasional Bantimurung Bulusaraung.

Peraturan Pemerintah No. 7 tahun 1999 (Departemen Kehutanan, 1999a) menyebutkan bahwa pembinaan habitat dapat dilaksanakan melalui penanaman dan pemeliharaan pohon pelindung dan sarang satwa namun sebagian besar pohon pelindung dan sarang atau pakan satwa tersebut seringkali merupakan jenis-jenis yang tidak dikenal sehingga metode penanaman belum banyak diketahui. Uji coba pemberian kompos di awal penanaman dilakukan sebagai upaya mendapatkan metode penanaman yang tepat untuk optimalisasi pertumbuhan tanaman M. minutum.

M. minutum merupakan tumbuhan pakan larva kupu-kupu jenis Papilio paranthus adamathius yang ditemukan di Taman Nasional Bantimurung Bulusaraung (Suryanto et al 20I4). Sekitar I 5 jenis Kupu-kupu yang ada di dalamnya, masuk dalam daftar perdagangan kupu-kupu internasional yaitu Troides cellularis, T. halipron, T. hypolitus, Papilio gigon, P. sataspes, P. ascalaphus, P. blumei, P. adamanthius, Graphium milon, $G$. meyeri, $G$. rhesus, $G$. androcles, $G$. deucalion, G. anceledes dan Chilasa veiovis. (Balai Konservasi Sumber Daya Alam Sulawesi Selatan I, 2005).

\section{BAHAN DAN METODE}

\section{A. Lokasi dan Waktu Penelitian}

Kegiatan dilaksanakan dari bulan Maret sampai Desember 2012 di kawasan TN Bantimurung Bulusaraung. Lokasi pengamatan di Pampang resort Pattunuang-Karaenta.

Bahan utama yang digunakan dalam kegiatan ini adalah bibit tanaman M. minutum yang berasal dari materi generatif yang diperoleh dari kawasan TN Bantimurung Bulusaraung. Alat yang digunakan dalam penelitian untuk penanaman berupa sabit, cangkul dan sekop, sedangkan untuk pengukuran dan pencatatan pengamatan menggunakan pita ukur, alat tulis dan kertas.

\section{B. Tahapan Pelaksanaan kegiatan}

I. Penyiapan lahan

Pembersihan areal sebelum penanaman perlu dilakukan dengan harapan kondisi pertumbuhan tanaman hanya merupakan pengaruh dari perlakuan yang diberikan, area pertanaman dikelompokan dalam blok-blok. Pembuatan lubang tanam dengan pemasangan ajir dan penggalian lubang tanam dengan ukuran $30 \mathrm{~cm} \times 30 \mathrm{~cm} \times 30 \mathrm{~cm}$ dan jarak tanam 2 meter $\times 2$ meter.

\section{Penanaman}

Tanaman pokok ditanam berdasarkan perlakuan takaran pupuk kandang yang diberikan yaitu 0, 300, 600 dan 900 gram/lubang. Pemberian pupuk dilakukan beberapa lama sebelum tanaman di letakkan pada lubang tanam. 
3. Pemeliharaan tanaman uji

Pemeliharaan tanaman berupa pendangiran tanaman uji coba, meliputi: pembabatan rumput di sekitar tanaman pokok dengan diameter $50 \mathrm{~cm}$, pencangkulan di sekitar tanaman pokok dengan diameter 50 $\mathrm{cm}$, pengambilan akar-akar rumput dan penggemburan tanah. Kegiatan pendangiran dilakukan setiap tiga bulan sekali atau 4 kegiatan dalam setahun.

4. Pengamatan pertumbuhan dan kesehatan tanaman ujicoba

a. Pengamatan pertumbuhan tanaman uji coba dilakukan dengan melakukan pengukuran tinggi, diameter tanaman dan jumlah daun. Pengukuran tanaman dilakukan setiap 3 bulan sekali untuk mengetahui perkembangan tanaman.

b. Kesehatan tanaman diamati dengan pengamatan secara visual terhadap bagianbagian tanaman. Pencatatan dilakukan jika ditemukan hama atau penyakit. Pengamatan kesehatan dilakukan bersamaan dengan pengamatan pertumbuhan.

\section{Analisa Data}

Data hasil pengamatan pertumbuhan tanaman uji coba dianalisa dengan analisis varian selanjutnya apabila terdapat perbedaan nyata akan dilakukan Uji Lanjut Jarak Berganda Duncan (DMRT).

\section{HASIL DAN PEMBAHASAN}

Larva kupu-kupu memanfaatkan bagian daun M. minutum sebagai pakan untuk tumbuh dan berkembang. Hasil pengamatan menunjukkan persen hidup tanaman ujicoba di lapangan pada empat perlakuan pemupukan menunjukkan nilai rata-rata di atas $90 \%$ atau tergolong dalam high rate survival (Gambar I).
Penanaman lada-lada dengan ujicoba pemupukan dapat digolongkan dalam kriteria baik. Sebagaimana disebutkan oleh Stein (1978) bahwa keberhasilan penanaman didasarkan pada kriteria gagal bila pertumbuhan $0-9 \%$, rendah untuk $0-39 \%$, cukup untuk 40 - $69 \%$ dan baik untuk 70 $100 \%$.

Penanaman M. minutum merupakan upaya peningkatan populasi satwa kupu-kupu melalui penanaman tanaman pakan maka pengamatan produktivitas tanaman untuk menghasilkan daun sebagai pakan ulat dengan menghitung jumlah daun per tanaman perlu dilakukan. Pembentukan daun ditentukan oleh unsur hara yang ada dalam tanah terutama unsur nitrogen dan fosfor sebagai pembentuk jaringan. Kedua unsur hara ini berperan dalam pembentukan sel-sel baru dan komponen utama penyusun senyawa organik dalam tanaman yang memengaruhi pertumbuhan vegetatif tanaman, khususnya peningkatan jumlah daun (Haryadi et al. 2015). Perlakuan takaran pupuk kandang diharapkan memberi pengaruh pada ketersediaan unsur hara yang ada pada tanah sehingga berakibat pada peningkatan pertumbuhan dan pembentuk daun M. minutum.

Dewi et al. (2017) menyebutkan bahwa kotoran sapi memiliki kandungan kimia berupa nitrogen 0,4 - I\%, phospor $0,2-0,5 \%$, kalium 0,1 - I,5\%, kadar air 85 - 92\%, dan beberapa unsur-unsur lain (Ca, $\mathrm{Mg}, \mathrm{Mn}, \mathrm{Fe}, \mathrm{Cu}, \mathrm{Zn}$ ). Besarnya jumlah nitrogen dan fosfor memberikan pengaruh pada jumlah daun yang dihasilkan $M$. minutum. Hasil Duncan's Multiple Range Test (DMRT) menunjukkan bahwa aplikasi pemupukan memberikan pengaruh yang berbeda nyata pada jumlah daun yang dihasilkan (Tabel 2). 


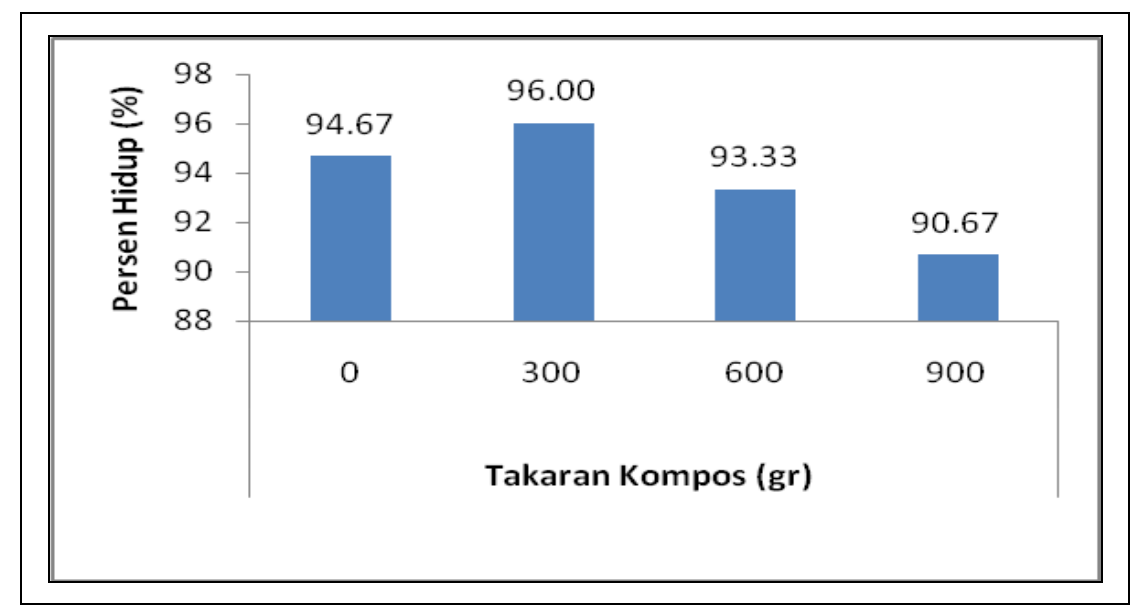

Gambar I. Persen hidup M. minutum dengan perlakuan pemupukan per lubang tanam Figure I. Percent of life of M. minutum with the treatment of fertilizing each planting hole

Tabel I.Sidik ragam ujicoba takaran pupuk pada M. minutum Table I.Sidik variety trials on M.minutum fertilizer

\begin{tabular}{|c|c|c|c|c|c|c|}
\hline \multirow{2}{*}{$\begin{array}{l}\text { Sumber } \\
\text { keragaman } \\
\text { (Source of } \\
\text { diversity) }\end{array}$} & \multicolumn{2}{|c|}{$\begin{array}{l}\text { Tinggi } \\
\text { (Hight) }\end{array}$} & \multicolumn{2}{|c|}{ Diameter } & \multicolumn{2}{|c|}{$\begin{array}{c}\text { Jumlah daun } \\
\text { (Number of Leaves) }\end{array}$} \\
\hline & $\begin{array}{l}\text { Rerata } \\
\text { Kuadrat } \\
\text { (Average } \\
\text { Squares) }\end{array}$ & $\begin{array}{l}\text { F. hitung } \\
\text { (F. count) }\end{array}$ & $\begin{array}{c}\text { Rerata } \\
\text { Kuadrat } \\
\text { (Average } \\
\text { Squares) }\end{array}$ & $\begin{array}{l}\text { F. hitung } \\
\text { (F. count) }\end{array}$ & $\begin{array}{l}\text { Rerata } \\
\text { Kuadrat } \\
\text { (Average } \\
\text { Squares) }\end{array}$ & $\begin{array}{l}\text { F. hitung } \\
\text { (F. count) }\end{array}$ \\
\hline $\begin{array}{l}\text { Takaran pupuk } \\
\text { (Fertilizer dose) }\end{array}$ & 2866.432 & $7.090 * *$ & 19.043 & $3.704 * *$ & 440208.869 & $2.639 * *$ \\
\hline Blok (Block) & 28651.325 & $70.863 * *$ & 339.287 & $65.991 * *$ & 9116922.323 & $54.648 * *$ \\
\hline Galat (Error) & 404.319 & & 5.141 & & $|66830.5| \mid$ & \\
\hline
\end{tabular}

Keterangan : (Remarks:)

* $\quad=$ Berbeda nyata pada taraf uji $5 \%(*=$ real contrast at test level $5 \%)$

** = Sangat berbeda nyata pada taraf uji $5 \%$ (Very significantly different from the test level of $5 \%$ )

Ns = Tidak berbeda nyata pada taraf 5 (Not significantly different at level 5\%)

Nilai tertinggi pada takaran pupuk 600 gram dengan jumlah daun rata-rata sebesar 662.86 . Hasil sidik ragam tinggi, diameter dan jumlah daun tanaman ujicoba penanaman pada Tabel I menunjukkan nilai rata-rata tinggi, diameter dan jumlah daun berbeda nyata sedangkan hasil uji lanjut Duncan tampak bahwa perlakuan kontrol tampak memberikan nilai rata-rata tertinggi untuk parameter tinggi dan diameter tanaman dengan nilai tinggi tanaman rata-rata sebesar $62,76 \mathrm{~cm}$ dan nilai diameter tanaman sebesar $5,98 \mathrm{~mm}$ (Tabel 2). Pertumbuhan tanaman belum optimal hingga umur tanaman 24 bulan. Klorosis atau kondisi daun menguning pada awal penanaman menjadi faktor penyebab pertumbuhan $M$. minutum tidak optimal.

Lokasi ujicoba penanaman merupakan lokasi yang tidak jauh dari sebaran alam $M$. minutum, sehingga faktor lingkungan yang berpengaruh terhadap pertumbuhan adalah sama. namun demikian satu faktor penting yang perlu dicermati dalam penanaman adalah sifat fisik dan kimia tanah area penanaman. 
Tabel 2. Duncan's Multiple Range Test (DMRT) takaran pupuk kandang per lubang tanam pada Micromelum minutum

Table 2. Duncan Multiple Range Test (DMRT) dose of manure per planting hole on Micromelum Minutum

\begin{tabular}{cccc}
\hline $\begin{array}{c}\text { Takaran pupuk } \\
\text { (Fertilizer dose) }\end{array}$ & Tinggi (hight) $\mathbf{( c m )}$ & Diameter $(\mathbf{m m})$ & $\begin{array}{c}\text { Jumlah daun } \\
\text { (Number of Leaves) }\end{array}$ \\
\hline 900 & $49.14 \mathrm{a}$ & $4.63 \mathrm{a}$ & $481.82 \mathrm{a}$ \\
300 & $49.74 \mathrm{a}$ & $4.76 \mathrm{a}$ & $558.61 \mathrm{a}$ \\
600 & $53.47 \mathrm{a}$ & $5.61 \mathrm{~b}$ & $662.86 \mathrm{~b}$ \\
0 & $62.76 \mathrm{~b}$ & $5.98 \mathrm{~b}$ & $620.86 \mathrm{ab}$ \\
\hline
\end{tabular}

Catatan : Nilai pada kolom yang diikuti huruf yang sama tidak berbeda nyata pada taraf $5 \%$ berdasarkan uji jarak berganda Duncan

Note: The values in the column followed by the same letters are not significantly different at the $5 \%$ level based on Duncan's multiple distance test

Adanya cekaman air akibat kondisi tanah dengan drainase tanah cepat menyebabkan terjadinya klorosis pada daun. M. minutum merupakan tanaman yang tidak toleran terhadap cekaman air sehingga berakibat terjadinya klorosis dan pertumbuhan tanaman tidak optimal. M minutum dapat tumbuh baik pada tanah dengan drainase lambat. Cekaman atau kekurangan air menyebabkan klorosis dimana perubahan warna daun diawali dari bagian atas atau pucuk kemudian turun ke daun bagian bawah. Klorosis adalah suatu kondisi tanaman mengalami kekurangan klorofil yang berfungsi sebagai pigmen penangkap cahaya untuk fotosintesis.

Energi yang dihasilkan dari fotosintesis akan digunakan tumbuhan untuk melangsungkan hidup dan melakukan berbagai reaksi serta untuk aktivitas tumbuhan sehingga apabila klorofil kurang atau klorosis maka semua proses tersebut tidak berjalan dan semua sel akan mengalami kematian jaringan atau nekrotik yang berakibat pada kematian terhadap tumbuhan (Putu, 20II). Kondisi demikian menyebabkan daun tidak lagi sesuai untuk dimanfaatkan sebagai pakan larva atau ulat kupu-kupu. Kematian tanaman $M$. minutum dapat dihindarkan akibat adanya intensitas curah hujan tinggi pada akhir pengamatan.

Pengamatan laju pertumbuhan tanaman menujukkan nilai rata-rata tinggi dan diameter tanaman ujicoba pada awal penanaman hingga 12 bulan tampak tidak berbeda nyata, namun pertumbuhan tanaman pada bulan berikutnya menunjukkan pergerakan signifikan. Besarnya pertumbuhan tanaman pada perlakuan kontrol menunjukkan bahwa kadar pemupukan tampak belum berpengaruh terhadap pertumbuhan tanaman. Taufika (2006) menyebutkan bahwa adanya interaksi berbagai faktor internal pertumbuhan yaitu atas kendali genetik dan unsur-unsur iklim, tanah dan biologis juga berpengaruh terhadap tidak terdapatnya pertambahan tinggi tanaman.

Ketidaksesuaian faktor lingkungan menjadi penyebab pertumbuhan tanaman tidak optimal. Intensitas hujan yang rendah pada bulan ke tiga setelah penanaman dengan karakter fisik tanah yang memiliki drainase cepat menyebabkan beberapa 
tanaman mengalami klorosis. Penambahan unsur hara hingga umur tanaman 24 bulan belum mampu memberikan pengaruh terhadap pertumbuhan tanaman.

Grafik pertumbuhan tinggi tanaman menunjukkan laju yang berbeda nyata hingga umur tanaman 24 bulan (Gambar 2). Demikian pula nilai rata - rata diameter takaran pupuk 300,600 dan 900 gr hingga 24 bulan berbeda laju pertumbuhan diameter pada tanaman (Gambar 3).

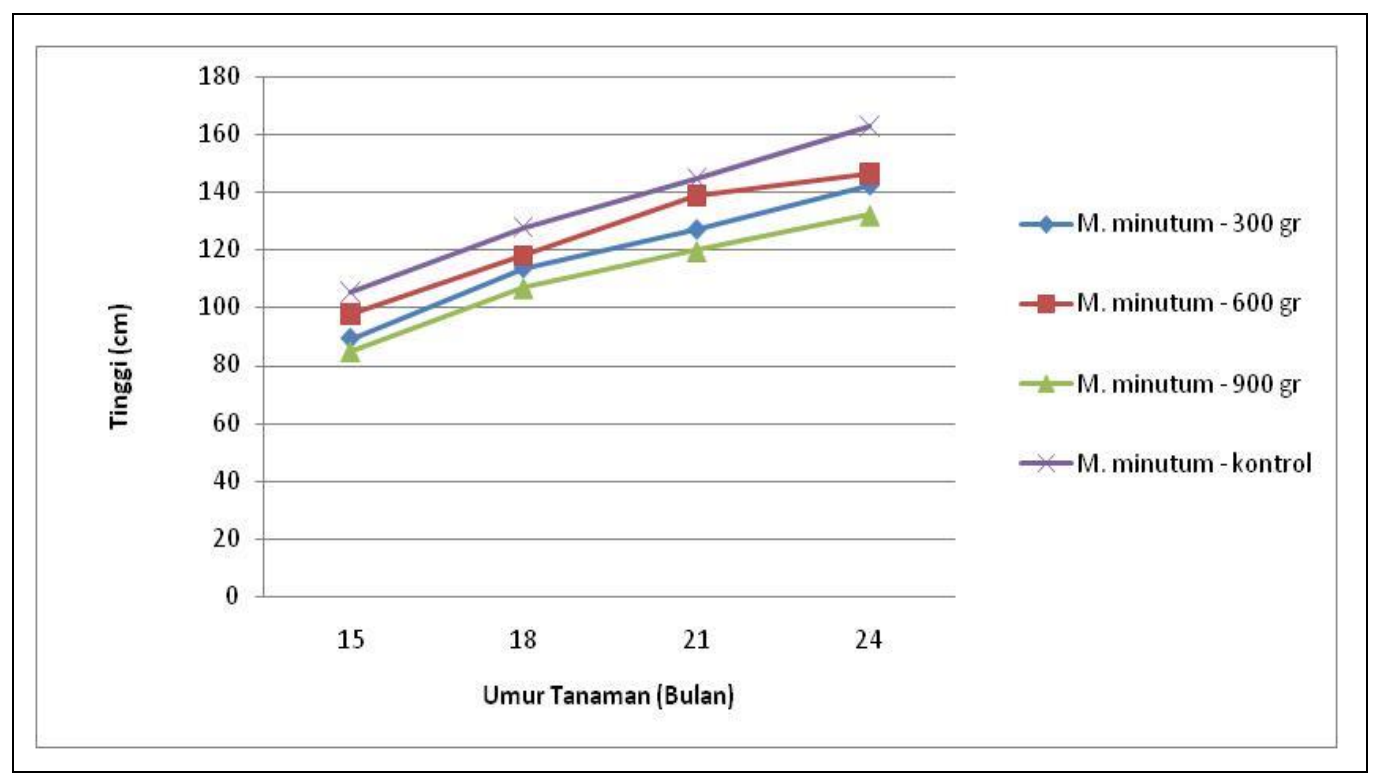

Gambar 2. Grafik rata-rata pertumbuhan tinggi Micromelum minutum Figure 2. Graph of high growth average of Micromelum Minutum

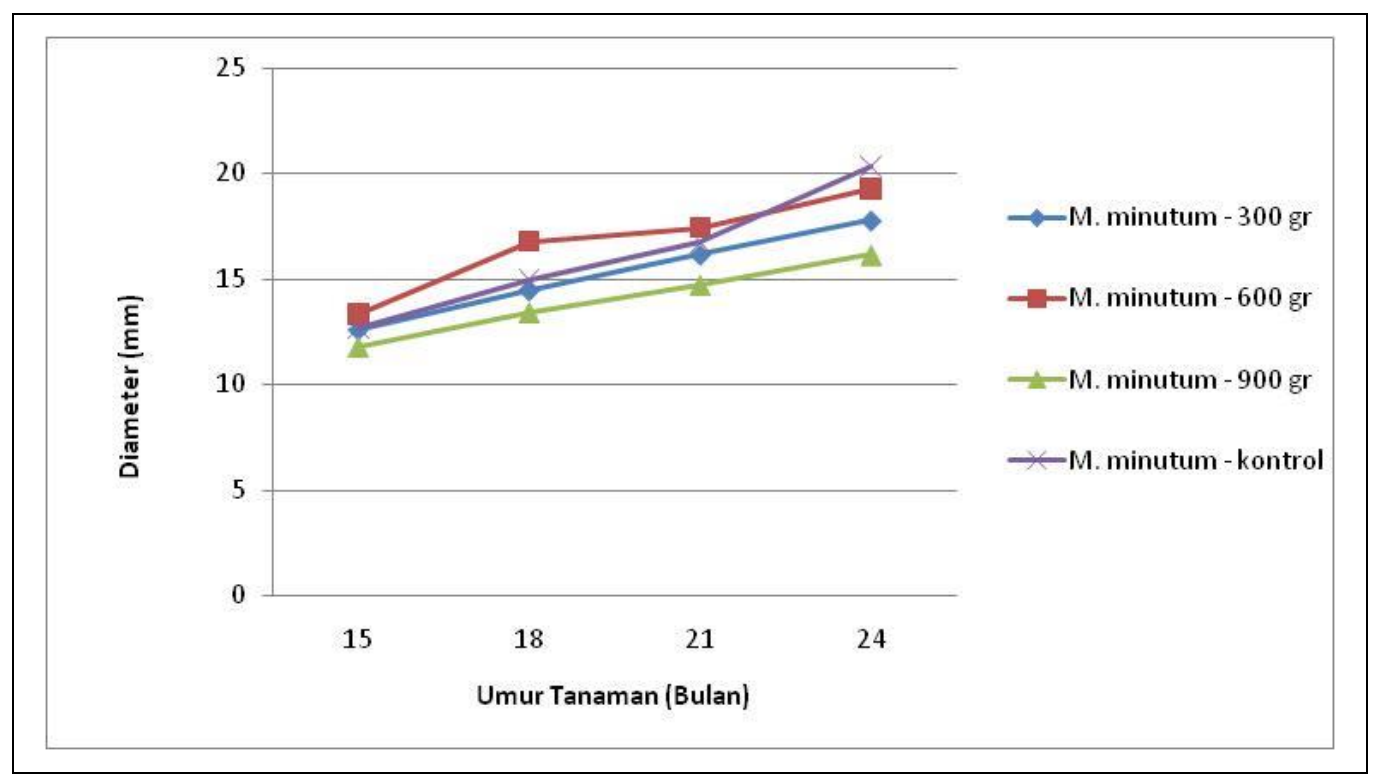

Gambar 3.Grafik rata-rata pertumbuhan diameter $M$. minutum di lapangan Figure 3.Grafik average diameter growth of $M$. minutum in field 
Kondisi tanah dengan drainase cepat memberikan pengaruh terhadap pertumbuhan tinggi dan diameter. Tanggapan tanaman terhadap suatu unsur hara tergantung pada ketersedian unsur hara yang lain serta adanya pengaruh lingkungan (Fahmi et al. 20l0). Klorosis yang terjadi pada awal penanaman berpengaruh terhadap pertumbuhan tanaman secara keseluruhan yang terjadi hingga umur tanaman 24 bulan. Penambahan unsur hara melalui pemupukan tampak belum memberikan pengaruh pada perkembangan diameter tanaman.

\section{KESIMPULAN DAN REKOMENDASI}

I. M. minutum tumbuh baik pada tanah dengan drainase lambat.

2. Penanaman M. minutum dengan takaran 600 gram memberikan hasil terbaik.

\section{Ucapan Terima Kasih}

Penelitian ini bagian dari kegiatan penelitian teknik pembinaan habitat di TN Bantimurung Bulusaraung di Balai Penelitian Lingkungan Hidup dan Kehutanan Makassar, Sulawesi Selatan. Ucapan terima kasih saya sampaikan kepada Bapak Muhammad Syarif S.Hut dan Bapak Abdul Qudus Toaha, S.Hut yang telah banyak memberikan bantuan dan masukan selama pelaksanaan kegiatan penelitian ini hingga selesainya penulisan naskah.

\section{DAFTAR PUSTAKA}

Balai Konservasi Sumber Daya Alam Sulawesi Selatan, 2005. Eksplorasi pakan Kupu-kupu Di Taman Nasional Bantimurung
Bulusaraung. Laporan pembinaan habitat (Tidak dipublikasikan). Balai Konservasi Sumber Daya Alam Sulawesi Selatan I. Direktorat Jenderal Perlindungan Hutan dan Konservasi Alam. Departemen Kehutanan. Makassar. Sulawesi Selatan

Departemen Kehutanan. 1999a. Peraturan Pemerintah No. 7 tahun 1999 tentang pengawetan jenis tumbuhan dan satwa. http://www.dephut.go.id. di akses tanggal I8 Maret 2010.

Dewi, N.M.E.Y., Setiyo. Y., Nada, I.M., 2017. Pengaruh bahan tambahan pada kualitas kompos kotoran sapi. Jurnal Biosistem dan Teknik Pertanian.5(I) Program Studi Teknik Pertanian, fakultas Teknologi pertanian Udayana.

Fahmi. A., Syamsuddin, Utami. S. N. H., Radjagukguk B. 2010 Pengaruh interaksi hara nitrogen dan fosfor terhadap pertumbuhan tanamn jagung (Zea mays L.) Pada tanah regosol dan latosol. Jurnal Berita Biologi.I0(3). Lembaga Ilmu Pengetahuan Indonesia.

Haryadi.D., Yetti. H., Yoseva, S., 20I5. Pengaruh pemberian beberpa jenis pupuk terhadap pertumbuhan dan produksi tanaman kalian. Fakultas Pertanian. Universitas Riau.

Putu. 20I I. Klorosis. http://WWW. Biolovers.com. Diakses tanggal 20 Januari 2012

Suryanto. H., Mangopang. A.D., 20I4. Perbanyakan tumbuhan pakan kupu-kupu untuk konservasi eksitu dan insitu Kupu Kupu di Taman Nasional Bantimurung. Fakultas Kehutanan Universitas Hasanuddin.

Taufika, R. 20l4. Jurnal Tanaman Hortikultura. http://repository.unand.ac.id/I7098/I/JUR NAL_RAHMI_TAUFIKA_\%2807III0I7\% 29.pdf. Diakses tanggal I5 Desember 2013. 
Jurnal FALOAK Vol. 3 No.I April 2019: 51-58 